\title{
Embracing Blockchain Applications in Fundamental Analysis for Investment Management
}

\author{
Audrey Lim Li Chin* \\ Faculty of Business, Multimedia University (MMU) \\ Malaysia

\section{Wong Wai Wai} \\ Faculty of Law, Multimedia University (MMU) \\ Malaysia
}

*Corrosponding author's Email: audreylim8@gmail.com 


\section{Research High Iight s}

The attributes of blockchain; efficiency in asset transfer, data accuracy, time-stamped transaction and transparency applications are postulated to have positive effects on fundamental analysis. Psychological factor such as herding may affects fundamental analysis which in turn affects investment decision making. Herding is not necessarily always deemed to be an irrational or negative factor. Investors who are affected by herding may still be able to invest in a rational manner and make a profit. With greater transparency in information and better data quality offered by Blockchain applications, herding behaviour by instititional investor could improve the stock valuation as well as the stock market fundamentals. These could be utilised by individual investors to make better and informed decision for stock picking. However, this is may only applicable to reputational herding.

\section{Research Objectives}

Numerous local as well as international reports have concluded that the participation of individual investors in the share market are declining with no improvement in sight. Retail participation stands at 14.6 percent as of January 2018, (The Edge Malaysia, 2018). Besides this, the vibrancy of Bursa Malaysia is falling behind its Asian counterparts, like Hong Kong and Singapore (Bursa Malaysia, 2015). One of the drivers that impacts market liquidity is market transparency. Market transparency increases the liquidity of markets. Accurate, relevant and timely reliable data on the market situation helps market participants also reduce uncertainty and hence reduce irrational risk-taking participation in the market that contribute to a market crash. The paramount objective of this study is to highlight the impacts of this revolutionary Blockchain technology, namely its super efficiency in asset transfer, data accuracy, irreversible transaction and transparency in fundamental analysis that could significantly implant greater confidence amongst potential investors. Essentially, fundamental analysis is used for long-term predictions of values of future phenomena based on historical data and a set of other factors which may affect the level of demand and supply (Krzywda, 2010). Fundamental analysis also studies the economic bases of companies (Borowski , 2014) by using financial statements and current information about the company to determine future values of its shares (Hong \& Wu, 2016; Edirisinghe \& Zhang, 2008; Pomykalska \& Pomykalski, 2008). 


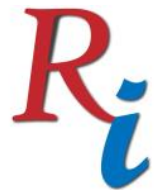

Asia Proceedings of Social Sciences

(APSS)

www.readersinsight.net/APSS

\section{Methodology}

A conceptual framework is developed and the following propositions are developed:

Proposition 1: Attributes of blockchain applications have positive effects on fundamental analysis.

1a: Efficiency in Asset Transfer has a positive effects on fundamental analysis.

1b: Data Accuracy has a positive effects on fundamental analysis.

1c: Time-Stamped Transaction has a positive effects on fundamental analysis.

1d: Transparency has a positive effects on fundamental analysis.

Proposition 2: Herding is significantly affecting fundamental analysis.

Proposition 3: Herding is significantly affecting investment decision making.

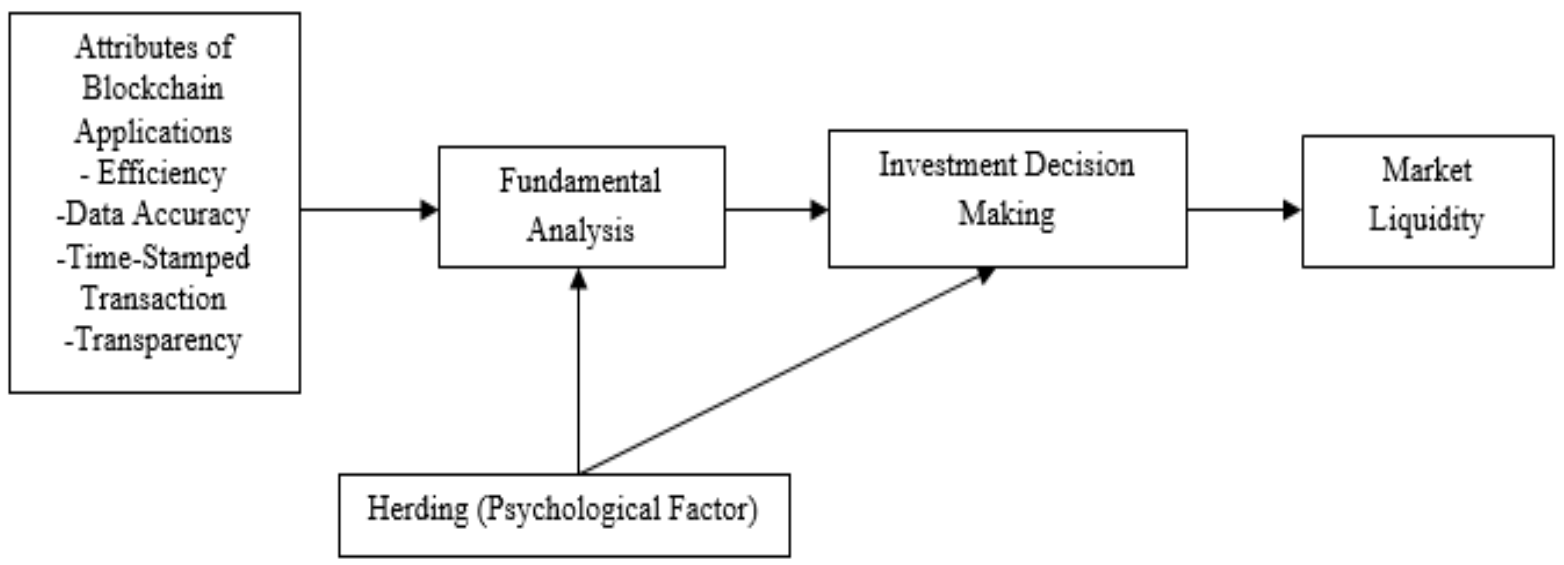

Conceptual Framework illustrating the relationship between blockchain's attributes, fundamental analysis, herding, investment decision making and market liquidity

\section{Results and Findings}

The attributes of blockchain; efficiency in asset transfer, data accuracy, time-stamped transaction and transparency applications are suggested to have positive effects on fundamental analysis. Blockchain technology is a decentralized peer-to-peer network which can be used to embed information and instructions with a wide range of applications. When investors are able 


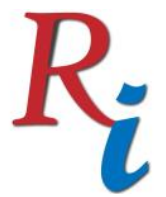

\section{Asia Proceedings of Social Sciences \\ (APSS) \\ www.readersinsight.net/APSS}

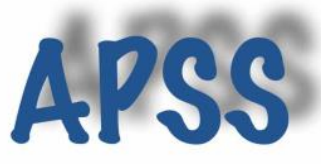

to buy and sell stocks through a decentralized peer-to-peer network that is easy to use and fast, this would contribute to higher level of efficiency in the stock market. With the cloud based management tool (LINQ), Blockchain system records data, with irreversible, time-stamped transactions, managers of company will not be able to adopt strategies such as backdating sales contracts prior reporting period. When manipulation of quarterly earnings became less relevant or important due to real-time accounting, it will greatly reduce distortion in firms' investment policies (Yermack, 2017). Transparency is also one of the most important factors affecting the company's attractiveness to investors (Mohammadi \& Nezhad, 2015).Though, with greater real-time data and information transparency, the quality of decision making can be enhanced while stimulating the investors' participation and market liquidity when not all investors are equipped with the knowledge and sufficient level of financial literacy to conduct their own fundamental analysis in their investment decision making. Investors may still be susceptible to psychological bias such as herding behaviours in which they tend to mimick the actions or decisions of the other investors. Although herding stimulate market participation, increase liquidity, herding also produce emotional, irrational risk-taking investment decision which contributes to market failure and crashes.

\section{References}

Borowski, K. (2014). Analiza fundamentalna. Metody wyceny przedsiębiorstwa (Fundamental Analysis. Company Valuation Methods). Difin SA, Warszawa.

Edirisinghe, N. C. P., \& Zhang, X. (2008). Portfolio Selection under DEA-Based Relative Financial Strength Indicators: Case of US Industries. Journal of the Operational Research Society, 59(6), 842-856.

Hong, K., \& Wu, E. (2016). The Roles of Past Return and Firm Fundamentals in Driving US Stock Price Movements. International Review of Financial Analysis, 43, 62-75.

Krzywda, M. (2010). GPW II. Akcje i analiza fundamentalna w praktyce (Shares and Fundamental Analysis in Practice). Wydawnictwo Złote Myśli, Gliwice.

Mohammadi, S., \& Nezhad, B. M. (2015). The role of disclosure and transparency in financial reporting. International Journal of Accounting and Economics Studies, 3(1), 6062.

Pomykalska, B., \& Pomykalski, P. (2008). Analiza finansowa przedsiębiorstwa (Financial Analysis of a Company). Wydawnictwo Naukowe PWN, Warszawa.

Yermack, D. (2017). Corporate Governance and Blockchains. Review of Finance, 7-31. 